\author{
A. Seidikenova ${ }^{1 * i D}$, M. Malshy ${ }^{1}$, A. Akkari $^{2 i}$ \\ ${ }^{1}$ Al-Farabi Kazakh National University, Kazakhstan, Almaty \\ ${ }^{2}$ University of Geneva, Switzerland, Geneva \\ *e-mail: almash.seidikenova@kaznu.kz
}

\title{
LANGUAGE ANXIETY IN ONLINE EDUCATION
}

Anxiety on the lessons of a foreign language - is a notion that is studied from the 1980s, but little research was conducted on the topic Language Anxiety distance and online learning. In the literature review were considered the following issues: (a) What is language anxiety in the classroom of a foreign language? (b) What are the main results of studies of the level of anxiety in foreign language lessons? The article discusses a test system for determining the level of linguistic anxiety in foreign language lessons, which was developed by Horwitz and Cope (1986). Language anxiety on the classes of foreign language may have negative impact on process of the second language acquisition. Current article refers to the problem of language anxiety in teaching foreign language at distance and possible solutions of decreasing language anxiety. Psychological aspect is a crucial part of educational process that leads to successful learning. Recommendations provided in the following article may help students to feel less isolated, less anxious and to establish contacts with their teacher and peers. The article concludes with suggestions for future research on online language anxiety.

Key words: language anxiety, online learning, distance learning, language learning, online technologies, teaching methods, online pedagogy, methodology, teaching foreign languages, remote learning.

\section{А.С. Сейдикенова ${ }^{*}$, М. Малшы ${ }^{1}$, А. Аккари ${ }^{2}$}

'Әл-Фараби атындағы Қазақ ұлттық университеті, Қазақстан, Алматы к.

${ }^{2}$ Женева Университеті, Швейцария, Женева қ.,

*e-mail: almash.seidikenova@kaznu.kz

\section{Языковая тревожность в онлайн обучении}

Шетел тілі сабақтарындағы үрей - бұл 1980 жылдардан бері зерттеле бастаған тұжырымдама, бірақ қашықтықтан және желілік оқыту тұрғысынан «Тілдік үрей» тақырыбында аз зерттеулер жүргізілген. Әдеби шолуда келесі сұрақтар қарастырылды: а) шет тілі сабағындағы тілдік үрей дегеніміз не? б) шет тілі сабақтарындағы үрей деңгейін зерттеу нәтижелері қандай? Мақалада Хорвитц пен Коуп (1986) жасаған шетел тілі сабақтарындағы тілдік қорқыныш деңгейін анықтауға арналған тест жүйесі талқыланады. Тілдік үрей екінші тілді меңгеруге кедергі келтіруі және оқу процесіне кері әсер етуі мүмкін. Қазіргі уақытта ғаламдық пандемия аясында стресс пен студенттерге қысым күшейді, бұл өз кезегінде жаңа материалды игеруде қиындықтар туғызды. Бұл мақалада шет тілін қашықтықтан оқытудағы лингвистикалық үрей мәселесі және лингвистикалық алаңдаушылықты төмендетудің мүмкін шешімдері қарастырылған. Психологиялық аспект - бұл білім беру процесінің маңызды бөлігі, ол табысты білім беру процесіне әкеледі. Келесі мақаладағы кеңестер студенттерге оқшаулануды, қорқынышты сезінуге, мұғалімімен және құрдастарымен байланыс орнатуға көмектеседі. Мақала қашықтықтан білім берудегі тілдік үрей туралы болашақ зерттеулерге арналған ұсыныстармен аяқталады.

Түйін сөздер: тілдік қорқыныш, желіде оқыту, қашықтықтан оқыту, тілді оқыту, онлайн-технологиялар, оқыту әдістері, онлайн-педагогика, әдістеме, шет тілдерін оқыту, қашықтықтан оқыту.

\author{
А.С. Сейдикенова ${ }^{1 *}$, М. Малшы ${ }^{1}$, А. Аккари ${ }^{2}$ \\ ${ }^{1}$ Казахский национальный университет имени аль-Фараби, Казахстан, г. Алматы \\ ${ }^{2}$ Женевский университет, Швейцария, г. Женева \\ *e-mail: almash.seidikenova@kaznu.kz
}

\section{Онлайн білім берудегі тілдік үрей}

Тревога на уроках иностранного языка - понятие, которое изучается с 1980-х годов, но мало исследований было проведено по теме «Языковая тревога» с точки зрения дистанционного и онлайн-обучения. В обзоре литературы были рассмотрены следующие вопросы: (а) Какова языковая тревога на уроках иностранного языка? (б) Каковы результаты исследования уровня тревожности на уроках иностранного языка? В статье обсуждается тестовая система для определения уровня языковой тревожности на уроках иностранного языка, разработанная Хорвицем и Коупом (1986). Языковая тревожность может повлиять на процесс усвоения второго языка и оказать негативное влияние на процесс обучения. В данной статье рассматривается проблема языковой тревожности на дистанционных занятиях иностранным языком и возможные решения по снижению языковой 
тревожности. Психологический аспект - важнейшая часть учебного процесса, ведущая к успешному учебному процессу. Рекомендации, приведенные в данной статье, могут помочь учащимся чувствовать себя менее изолированными, менее тревожными и установить контакты со своим учителем и сверстниками. Статья завершается предложениями для будущих исследований языковой тревожности в дистанционном образовании.

Ключевые слова: языковая тревога, онлайн-обучение, дистанционное обучение, изучение языков, онлайн-технологии, методы обучения, онлайн-педагогика, методология, преподавание иностранных языков, дистанционное обучение.

\section{Introduction}

Currently, in the context of a global pandemic, changes are taking place in the usual way of life and in the field of education. Students and schoolchildren around the world are forced to study remotely. While some teachers are proficient in teaching technologies and pedagogical skills, many of them were not prepared for distance teaching. In addition to the lack of devices and poor Internet connection, teachers also faced with the problem of online pedagogy. The interaction of three components, how to teach language (language pedagogy), educational technologies and online teaching (pedagogy for educational technology) and knowing how to teach online (online pedagogy) can lead to the successful implementation of the educational process of a foreign language in the context of distance education.

Given the large number of students currently pursuing online or distance education for language learning due to COVID-19, it is important to consider how external factors such as anxiety can hinder learning. In addition, foreign language teachers and their students had to move quickly and adapt to learning in an online environment without sufficient time or prior preparation and training. This problem is an additional cause of stress for both students and teachers. Remote learning can take different forms according to the type of the lessons, technological devices of learners, connection of the internet etc. Universities try to provide their students with various books and textbooks, however, many educators are operating in a triage mode, they try to conduct the most important outcomes of learning the subject and provide instructions using different tools that are available.

Scientists distinguish following strategies as factors that increase students` language level:

- motivation to learn the target language;

- being calm and relaxed on the lessons;

- choosing the exact form of language;

- being attentive to the context and meaning;
- making predictions and guessing;

- competence and control of speech;

- communication.

It is known that cognitive processes are associated with the brain functioning and the mind. However, it is not the only factor that affects the process of language acquisition, affective sphere which related to feelings and emotions have impact on this process as well. Individual's mental health and wellbeing affects to the quality of life in general and may cause negative outcomes.

Psychological factors (self-esteem, motivation, anxiety, etc.) are relevant to the process of second language acquisition. Motivation is one of the psychological factors that might be trigger to learn a language. Self-esteem of learners may affect to the results of the educational process. For educators it is important to courage their learners, while low self-esteem may lead to stiffness of student, which is often caused by the fear of making mistake or being corrected. Nevertheless, students that are not afraid to make mistakes are not supposed to make greater results and vice versa.. furthermore, students that tend to be more active on lessons could encourage less active students not to be afraid to perform.

Individuals in different situations manifest anxiety in different ways; its display is also influenced by the success of educational activities. Among the three levels of anxiety: high, medium and low - the optimal level of anxiety is medium. With a very low or very high level of anxiety, the success of the activity is significantly reduced.

\section{Literature Review}

The research by Krashen (1981) indicates that when language learners become anxious, a filter is raised in their minds that blocks linguistic input from entering; this is known as the hypothesis of "affective filter" (Krashen, 1981). Studies showed that anxiety may lead to poor performance in a language classes and have negative impact on the process of learning the language. 
It has to be mentioned that the research of language anxiety has difficulties in variety of interpretation of different types of anxiety; for example: situational anxiety and anxiety as a personality trait. Horwitz and Young (1991) present evidence that more than half of the students who begin to master a foreign language, experiencing the so-called " debilitative" level of language anxiety, in which there is a significant reduction in cognitive abilities (Horwitz, Young, 1991). Referring to different studies, authors noted the fact that linguistic anxiety has roots in the difficulties that individual experienced in learning his native language.

E. Horwitz , M. Horwitz and J. Cope (1991, 1986) noted that researchers have not yet given an adequate definition of the concept of "linguistic anxiety" and have not described its specific influence on the process of mastering a foreign language. The concept of "anxiety when learning a foreign language" (Foreign language anxiety while learning) sometimes replaces the term "language anxiety", the use of which emphasizes the connection between learning a foreign language with the anxiety that can accompany the process of learning a mother tongue (Horwitz, Horwitz, Cope, 1986). E. Horwitz and D. Young (1991) also point out that there are two parallel approaches to the identification of language anxiety: 1) language anxiety is a form of reflection of personal anxiety that about to appear in other areas, for example, in the exam situations; 2) linguistic anxiety is a unique form of anxiety that does not occur when mastering other disciplines (Horwitz, Young, 1991). These two approaches are not, however, contradicting to each other, because they contain different views on the definition division of language anxiety.

Language Anxiety can be defined as "a distinct complex of self-perceptions, beliefs, feelings, and behaviors related to classroom language learning arising from the uniqueness of the language learning process" (Horwitz, Horwitz, Cope, 1986). Such anxiety is a type which occurs while the process of language learning is happening in classroom conditions, and it does not occur in naturalistic settings, such as: immersion while traveling or moving abroad. Researcher Horwitz and colleagues (1986), summarized two major races considered above directions of studying the relationship of language anxiety with other kinds of anxiety, says that language anxiety has three main sources. Horwitz created a scale that measures the level of language anxiety in instructional settings, Foreign Language Classroom Anxiety Scale (FLCAS). This test system is appropriate to measure language anxiety in any type of class. Research by Pichette in 2009 and Russel in 2018 showed that online learners experience significant level of language anxiety (Russel, 2014).

Some learners who experience high level of language anxiety may choose online classes in order to conduct the lessons anonymously, however they need to engage in speaking and interaction with teacher or a group. Language learners usually need to interact with their peers, as language is a communication tools and integrating speaking skills is a crucial part of the educational process. Apart from this, learners might face anxiety related both to the language and to the use of instructional technologies that are used in order to communicate in the target language. In current situation, when all the learners are forced to have online lessons, this became even harder for the students who lack selfdiscipline and are not able to manage their personal time. Moreover, students having online lessons should be able to seek for help when needed and feel less isolated from their groupmates.

In the research by Pichette (2009) face-to-face learners and online learners of different levels were compared, in order to determine if online learners experience language anxiety less. Three measures were employed to make a profile of learner: FLCAS to measure general anxiety level, Foreign Language Reading Anxiety scale, Daly-Miller Writing Apprehension Test (Pichette, 2009). Quantitative analyses found no difference on anxiety levels of online and face-to-face learners. However, studies showed that advanced students conducting lessons online tend to feel less anxious after the first semester of studies, when they get used to the process of online education. However, it is unclear if lower level students experience less level of anxiety during online classes.

According to particular number of scientists, there is an interconnection between the level of language anxiety that students experience and their gender identity. According to the data of research conducted by Ilyin and Pasynkova, female learners at the age of 16-17 tend to be experience higher level if anxiety (Pasynkova, 1996). Due to the data obtained by Kuzakova that was conducted among adult learners showed that male learners experienced greater amount of anxiety (21\%), while female learners showed lower level of anxiety (14\%)

Psychologists differentiate the anxiety at the global notion which is inherent character trait, from the situational anxiety which is related with a particular situation, including language anxiety 
which occurs in the process of learning foreign language.

Well balanced communicational process between teachers and students is a specificity of the process of teaching foreign language as a subject. For learners, the process of second language acquisition and getting used to a foreign language and speech is important. Conducting the lessons via creating an language environment and teaching the specificities of the culture might also be important. This will contribute to the generation of outer motivation to learn the language. Nevertheless, a gnostic barrier might appear, where students may experience higher levels of language anxiety.

Language anxiety refers to a condition when learners might focus on the possible mistakes and failures of the speech, which leads to a negative impact on the process of education. In some cases it might be a consequence of individual features of a learner's personality as being anxious; there is a situational anxiety in other cases. In the first case, it exhausts the body, in the second; it promotes competition, providing intellectual tension. It is known that empathy, which is an ability of person to put himself to a position of a speaker. Empathy is important in maintaining successful communication in native language. However, it is not the fact that learners with a higher level of empathy will lead to greater results and vice versa. One of the important tasks for teacher is to establish comfortable interpersonal relationships with students which will contribute to lessen the level of anxiety,and help to increase learner's self-esteem and empathy. "Move away from the role of an "allknowing" teacher, becoming only an advisor and helping the student to make a "choice" of the form of this or that communication intention" (Arshava, 2006). It means that students need to have freedom of speech and thought.

Language anxiety mainly appears from the following three key sources: the anxiety that the students experience while communicating interpersonally, the fear of making a mistake and getting negative assessment; and the anxiety which appears while making the test works and checking.

Following points show main reasons that lead to increase of the language anxiety:

- Social factors; that are related to individual's confidence of self-presentation. This is caused by learner's proficiency in target language and his/her behavior.
- Personal factors of a speaker: introverted or shy learners and their self-esteem.

Significant level of anxiety can be seen on subjects where learners need to make a presentation and they are constantly being interrupted and each mistake of the student is under the control. Other sources show that student's with a higher-level competency tend to compare themselves to other students. "Students with a high level of linguistic anxiety are characterized by a very high level of fear of making a mistake, which generates anxiety" (Perevozchikova, 2005).

"An important aspect of language anxiety, which predetermines therelevanceofits studyinthecontextof an implicit assessment of emotional human stability, is that the latter has a negative impact on both the success of mastering academic activities, and on the processes of cognition and social interaction" (Horwitz, 2010). In order to reduce foreign language anxiety, it is crucial to create a specific program for learning a foreign language, which will reflect carious speech activities as speaking, listening, reading, and writing. It is crucial for this program to create pedagogically and psychologically relieve condition where the impact of outer stressors would be decrased and taken into account. Such kind of classes would encourage learners to adapt to online environment faster and increase learners' level of knowledge.

Results show that students who are having online classes may experience significant levels of language anxiety - especially in their first online course and that total level of language anxiety among learners are likely to rise due to the global pandemic and their rapid transition to online or distance learning, educators should consider introducing pedagogical interventions aimed at reducing the perceived level of students' language anxiety. Several studies - methods based on language relief anxiety can be gleaned from the literature; and since very few studies have examined language anxiety among online learners, it is useful to examine the pedagogical implications in the classroom - based research. Nevertheless, it is important to take into account that some of the concerns that online language learners have may be the result of the online environment and / or the use of new learning technologies. To reduce concerns about the technical aspects of language learning, Gertler recommended analyzing language development and digital literacy of learners at the start of a course, which can help teachers identify 
the types of support that learners need. be successful in the online learning environment. Goertler and Gacs, Goertler and Spasova have also suggested that instructors help students navigate the course so that they provide immediate feedback and develop coherent teacher and student roles (Goertler, 2011). While it may be difficult to provide immediate feedback to students, who can work at any time of the day and night, high-quality online language design and development includes the creation of the module " Getting Started ", which shows students how to navigate the course, where to find technical assistance and explore the educational technologies used to deliver the course, among many other key elements of targeting online learners. Using the same technologies throughout the course and from one course to the next will help students get used to them and are likely to reduce the anxiety associated with the technical aspects of language learning (Russel, 2020).

\section{Materials and methods}

Foreign Language Classroom anxiety scale was created by Horwitz in 1986 on the basis of scales that tested learner's anxiety (Sarason), Fear of negative evaluation (Watson and friends), and personal report of communication apprehension (McCroskey). FLCAS is still used to measure learner's perceived level of anxiety equally in online education and traditional face to face classes. The FLCAS consists of 33 questions rated in five levels from strongly agree (5 points) to strongly disagree ( 2 point). Score of anxiety is scaled by summing the scores of 33 questions. In order to assess the efficiency of the educator's interventions lead for reducing the level of foreign language anxiety of student's, it is useful for educator's to measure student's anxiety both at the beginning and at the end of the conducted course. FLCAS can be used in complex with a survey on student's context and needs. Results section of the current article provides information on the ways to implicate the current knowledge by suggesting techniques and methods that could be done to reduce the level of foreign language anxiety in terms of online education.

\section{Results and discussion}

Pedagogical implications. Several methods and interventions have been proposed in the literature to help reduce general language anxiety in students. Instructors can check out some of these educational events - using FLCAS as pre - and posttest - to determine their effectiveness in their online or distant learning languages.
- Remember that students studying in the online environment may also experience the same high levels of anxiety as students studying in traditional form, in addition they are required to download the tasks and recordings of the project works that were conducted with their groupmates. Make sure that you provide directions and instruction sessions before students need to download the tasks. This may also involve first a sequence of activities with lower cognitive load requirements.

- Ask students to express their concerns; they can do so orally (in pairs or small groups) or through journaling (Gregersen, 2014). On an online platform, this can also be achieved through written discussion forums or oral voice forums.

- Involve students in relaxation activities, the exercises such as special deep breathing while listening to music in the target language may be helpful. It is also important to ask students about their concerns or the reason of low attendance. It could be done through the written or oral forms.

- It is better to let students know about the cases of language anxiety and let them know that their anxiety will decrease over time and with language practice. Remind students that they are not alone and that you are here to support and encourage them during this stressful time.

- Increase interaction in the target language through the planned role - plays, thinks - a pair of conversations and group discussion; ask students to practice in pairs or small groups before asking them to speak to the whole class. Increased interaction and pairing can also help students cope with feelings of social isolation and loneliness during a pandemic.

- Practice makes perfect and repetition is important in helping students to overcome the language anxiety. Give students enough time to practice before oral presentations. Remind students that you don't expect excellence and that everyone makes mistakes when learning another language.

- Build student support systems where students would be able to discuss the process of language acquisition and teachers could make corrections misconceptions about language learning.

- Encourage students to immerse themselves in the language environment by reading or watching films / TV shows in the target language. Online teachers may consider setting up a language exchange for their students to provide additional exposure to the language being studied.

- Bare in mind the fact that students who do not complete the assignment, for example those who seem unprepared or they are being unresponsive, might be experiencing language anxiety; keep in mind that "... extremely anxious 
students have a strong motivation to avoid the classroom activities they fear most" (Horwitz, 2012).

In terms of the tools for online education, alFarabi Kazakh National University provided their students and teachers with the online library where more than 4500 books are available online, provided free access to the Microsoft programs and signed their accounts. These tools made the process of online education more convenient, when everyone have access to the platform.

However, students who live in rural are, economically disadvantaged students, learners without access to hardware are in a greater disadvantage. As we move to the future, this gap should be fulfilled. Since the beginning of the process of remote education educators and learners more or less got used to the process of online education. UNESCO provided the list of available tools and different application on their website, where they provide with the online education solutions for online education (https:// en.unesco.org/covid19/educationresponse/solutions). Another resource available is American Council on the teaching of Foreign Language, where they offer online instruction.

Solutions and resources provided are only part of the story. Another aspect is the fact that learners and educators were not prepared for the new learning environment and conducting the lesson from lockdown is causing significant stress. Apart from the problem of lacking the knowledge, many learners might also lack motivation, self-discipline and anxiety related to new technologies or general anxiety related to their home situation (lack of the available rooms, children, noisiness, no personal space, etc.). In this context, examining foreign language anxiety and steps instructors can take to reduce their students feeling of anxiety is very important. Despite the fact that alleviating all the anxiety related to the online education may not be possible, educators can help reduce the anxiety that students are feeling as a result of learning language online.

\section{Conclusion}

As online and distance language learning is currently taking place on a large scale across the country and the world, educators should consider implementing one or more of the research - based, pedagogical activities listed above to help ease their students' perceived levels of language anxiety. Teachers should select activities that they believe will be most appropriate for their students and for their own unique learning context. Given that most of the universities and the schools were largely unprepared for distance learning and training in the first school closing in 2020, it is crucial to language teachers to seek professional development in the online language pedagogy, as well as scientific - research - methods based on effective online language course design and delivery, if distance learning continues for a long period of time or that the schools are forced to close again from - for a pandemic after re - opening. Reach out to students with difficulty and offer advice on effective language learning strategies. This is especially important during distance learning when students are going through a series of life events in addition to learning a language. It may be necessary to telephone students who are completely disconnected from the course as they or their family members may be directly affected by COVID - 19. In these cases, students will require additional time and support to complete the course.

While most online educators and learners are integrating into the process of studies, researchers are seeking various ways and methods that would help to reduce the level of stress, increase the outcome of study and lessen the level of language anxiety on the classes of foreign language. Further studies on the topic of online learners and language anxiety will help educators and learners to overcome the problems related to language studies and anxiety related to the topic.

\section{References}

Goertler, S. (2011). Blended and open/online learning: Adapting to a changing world of language teaching. Present and future promises of CALL: From theory and research to new directions in language teaching, 471-502.

Gregersen, T., Macintyre, P. D., \& Meza, M. D. (2014). The motion of emotion: Idiodynamic case studies of learners' foreign language anxiety. The Modern Language Journal, 98(2), 574-588

Horwitz, E. K. (2010). Foreign and second language anxiety. Language Teaching, 43(2), 154.

Russell, V., \& Murphy-Judy, K. (2020). Teaching Language Online: A Guide for Designing, Developing, and Delivering Online, Blended, and Flipped Language Courses. Routledge.

Horwitz, E. (2014). Becoming a language teacher: A practical guide to second language learning and teaching. The CATESOL Journal, 25(1), 163-192.

Horwitz, E. K., \& Young, D. J. (1991). Language anxiety: From theory and research to classroom implications. Pearson College Div. Krashen, S. D. (1981). Second language acquisition and second language learning. University of Southern California. 
Pichette, F. (2009). Second language anxiety and distance language learning. Foreign Language Annals, 42(1), 77-93.

Russell, V. (2016). Promoting online language learners' perceptions of connectedness through pedagogical innovations. In Computer Assisted Language Instruction Consortium (CALICO) Conference, Michigan State University, East Lansing, MI.

Russell, V. (2016). Promoting online language learners' perceptions of connectedness through pedagogical innovations. In Computer Assisted Language Instruction Consortium (CALICO) Conference, Michigan State University, East Lansing, MI.

Arshava, I.F. (2006). Emocional 'naya stoikoist’ cheloveka b ego giagnostika. Dnepropetrovsk: Izd-vo DNU.

Pasynkova, R.N. (1996). Svyaz' urovnei trevozhnosti podrostkov s effektivnostiu ih intellectual’noi deiatel nosti. Pshychologicheskii zhurnal, 17(1), pp. 169-174

Perevezchikova, V.N. (2005). Psychologicheskie uslovya razvitya motivacii inoyazychnoi rechevoi deyatel'nosti studentov (Doctoral dissertation, Habarov. gos. pegagog. un-t). 